\title{
Pancreatic secretion in man with subclinical vitamin D deficiency
}

\author{
B. L. Nyomba ${ }^{1}$, J. Auwerx ${ }^{1}$, V. Bormans ${ }^{2}$, T. L.Peeters ${ }^{2}$, W. Pelemans ${ }^{3}$, J. Reynaert ${ }^{4}$, R. Bouillon ${ }^{1}$, G. Vantrappen ${ }^{2}$ \\ and P.De Moor ${ }^{1}$ \\ ${ }^{1}$ Laboratorium Experimentele Geneeskunde en Endocrinologie, ${ }^{2}$ Gut Hormone Laboratory and ${ }^{3}$ Geriatric Unit, Universitaire Ziekenhuizen, \\ Katholieke Universiteit Leuven, and ${ }^{4}$ Universitair Psychiatrisch Centrum St. Jozef, Kortenberg, Belgium
}

\begin{abstract}
Summary. The effects of subclinical vitamin D deficiency and vitamin D supplementation on oral glucose tolerance and secretion of pancreatic hormones were studied in 10 diphenylhydantoin-treated epileptic patients and 15 geriatric patients. Their mean serum concentrations of 25-hydroxyvitamin $\mathrm{D}_{3}$ and 1,25-dihydroxyvitamin $\mathrm{D}_{3}$ decreased markedly, but returned to normal within 2 weeks of oral supplementation with 25-hydroxyvitamin $D_{3}$. The serum concentration of ionized calcium was within the normal range before treatment, and remained unchanged. Serum parathyroid hormone was increased during vitamin $\mathrm{D}$ deficiency, but decreased significantly $(p<0.05)$ afterwards. In vitamin D-deficient epileptic and geriatric patients, the 2- and 3-h insulin levels after glucose ingestion were increased when compared with control
\end{abstract}

values, and glucagon secretion was not suppressed by glucose. Oral glucose tolerance of both groups of patients did not change after 25 -hydroxyvitamin $\mathrm{D}_{3}$ supplementation. Insulin secretion remained unchanged in geriatric patients, but was reduced to normal values in epileptic patients. Glucagon suppressibility by glucose was partly restored after vitamin D supplementation in epileptic patients but not in geriatric patients. In contrast to that observed in severely vitamin D-deficient rats or rabbits, correction of subclinical vitamin $D$ deficiency failed to enhance insulin secretion or to improve glucose tolerance in man.

Key words: Vitamin D, calcium, insulin, glucagon, glucose, anticonvulsants, geriatrics.
Several hormones influence the production of the active vitamin $\mathrm{D}$ hormone 1,25-dihydroxyvitamin $\mathrm{D}_{3}$ $\left(1,25-(\mathrm{OH})_{2} \mathrm{D}_{3}\right)$. Recent data also suggest a reciprocal influence of the vitamin $\mathrm{D}$ endocrine system on the secretion of these hormones. Indeed, parathyroid hormone, growth hormone, prolactin, oestrogens, thyroid hormones, and insulin modulate the renal biosynthesis of $1,25-(\mathrm{OH})_{2} \mathrm{D}_{3}$ [1]. Conversely, specific receptors for $1,25-(\mathrm{OH})_{2} \mathrm{D}_{3}$ have been found in parathyroid gland, pituitary and ovary. The vitamin D hormone also affects the secretion of various hormones and the growth of ovarian cells in culture [2].

Pancreatic B cells are also possible targets for vi$\operatorname{tamin} \mathrm{D}$, since they contain specific receptors for $1,25-(\mathrm{OH})_{2} \mathrm{D}_{3}[3]$ and a specific vitamin $\mathrm{D}$-dependent calcium binding protein [4]. In fact, few studies have shown that insulin secretion is reduced in vitamin D-deficient rats [5, 6] or rabbits [7], and that this defect can be corrected by vitamin $\mathrm{D}$ repletion but not by calcium alone $[7,8]$. Pharmacological doses of $1,25-(\mathrm{OH})_{2} \mathrm{D}_{3}$ could further increase insulin secretion in vitamin D-replete rats [9].

Little is known about the effects of vitamin $\mathrm{D}$ deficiency on the activity of the endocrine pancreas in man.
Moreover, since the activity of the pancreatic B cells also depends on the effect of other hormones [10], we examined the glucose-induced insulin response and the concomitant response of glucagon in vitamin D-deficient man before and after vitamin $\mathrm{D}$ repletion.

\section{Subjects and methods}

\section{Subjects}

The investigation was carried out in 10 epileptic patients (one male, nine females) with a mean age of 56 years and confined to a psychiatric clinic, and in 15 non-epileptic elderly patients (three males, $12 \mathrm{fe}$ males) aged 78 years and restricted to a geriatric home. The epileptic patients had been treated with a combination of barbiturates (mean dose: $200 \mathrm{mg} /$ day) and diphenylhydantoin (mean dose: $200 \mathrm{mg} /$ day) for a mean duration of 28 years (range 12-54 years). All the medications were kept constant during the course of the study. The geriatric patients were taking no medication known to interfere with calcium or glucose metabolism. The exposure to sunshine of both groups of patients was negligible, their vitamin $\mathrm{D}$ intake was estimated to average $250 \mathrm{IU}$ daily, and they ate about 2100 calories daily. Control values were obtained in 34 healthy adult subjects with a mean age of 50 years and in 61 non-institutionalized elderly subjects with a mean age of 77 years. Six subjects from either control group and all the patients volunteered for an oral glucose tolerance test. 
Table 1. Parameters of calcium metabolism in epileptic and geriatric patients during vitamin D treatment

\begin{tabular}{|c|c|c|c|c|c|c|c|c|}
\hline & \multicolumn{4}{|c|}{ Epileptic patients } & \multicolumn{4}{|c|}{ Geriatric patients } \\
\hline & $\begin{array}{l}\text { Before } \\
\text { treatment }\end{array}$ & $\begin{array}{l}1 \text { week after } \\
\text { treatment }\end{array}$ & $\begin{array}{l}2 \text { weeks after } \\
\text { treatment }\end{array}$ & $\begin{array}{l}\text { Control } \\
\text { values }\end{array}$ & $\begin{array}{l}\text { Before } \\
\text { treatment }\end{array}$ & $\begin{array}{l}1 \text { week after } \\
\text { treatment }\end{array}$ & $\begin{array}{l}2 \text { weeks after } \\
\text { treatment }\end{array}$ & $\begin{array}{l}\text { Control } \\
\text { values }\end{array}$ \\
\hline $\begin{array}{l}\text { Total calcium } \\
(\mathrm{mmol} / \mathrm{l})\end{array}$ & $2.17 \pm 0.03^{a}$ & $2.15 \pm 0.03^{\mathrm{a}}$ & $2.20 \pm 0.02^{\mathrm{b}}$ & $2.35 \pm 0.04$ & $2.28 \pm 0.02$ & $2.30 \pm 0.02$ & $2.30 \pm 0.20$ & $2.27 \pm 0.04$ \\
\hline $\begin{array}{l}\text { Ionized calcium } \\
(\mathrm{mmol} / \mathrm{l})\end{array}$ & $1.13 \pm 0.01$ & $1.14 \pm 0.04$ & $1.13 \pm 0.01$ & $1.14 \pm 0.03$ & $1.15 \pm 0.004$ & $1.17 \pm 0.005$ & $1.16 \pm 0.005$ & $1.13 \pm 0.02$ \\
\hline $\begin{array}{l}\text { Phosphorus } \\
\text { (mmol/l) }\end{array}$ & $0.94 \pm 0.06^{\mathrm{a}}$ & $1.00 \pm 0.07^{\mathrm{d}}$ & $1.00 \pm 0.08^{\mathrm{d}}$ & $1.07 \pm 0.07$ & $0.90 \pm 0.02^{\mathrm{a}}$ & $1.00 \pm 0.02^{b}$ & $1.13 \pm 0.14^{\mathrm{b}, \mathrm{d}}$ & $1.37 \pm 0.10$ \\
\hline $\begin{array}{l}\text { Alkaline phosphatase } \\
\text { (U/l) }\end{array}$ & $165 \pm 28^{b}$ & $159 \pm 21^{\mathrm{a}}$ & $164 \pm 26^{\mathrm{a}}$ & $78 \pm 6$ & $112 \pm 18$ & $112 \pm 18$ & $110 \pm 18$ & $121 \pm 10$ \\
\hline $\begin{array}{l}\text { Parathyroid hormone } \\
(\mathrm{mU} / 1)\end{array}$ & $174 \pm 82^{b}$ & $128 \pm 49^{\mathrm{b}}$ & $118 \pm 50^{\mathrm{b}}$ & $39 \pm 10$ & $129 \pm 26$ & $103 \pm 19$ & $110 \pm 20$ & $133 \pm 14$ \\
\hline $\begin{array}{l}25-\mathrm{OHD}_{3} \\
(\mathrm{nmol} / \mathrm{l})\end{array}$ & $17 \pm 3^{c}$ & $44 \pm 5^{e}$ & $36 \pm 6$ & $38 \pm 4$ & $19 \pm 3^{c}$ & $37 \pm 3^{e}$ & $35 \pm 3^{\mathrm{e}}$ & $42 \pm 3$ \\
\hline $\begin{array}{l}1,25-(\mathrm{OH})_{2} \mathrm{D}_{3} \\
(\mathrm{pmol} / \mathrm{l})\end{array}$ & $59 \pm 6^{c}$ & $104 \pm 12^{f}$ & $101 \pm 14^{f}$ & $122 \pm 10$ & $75 \pm 7^{c}$ & $111 \pm 10^{e}$ & $99 \pm 7^{e}$ & $105 \pm 6$ \\
\hline $\begin{array}{l}\text { Vitamin D-binding } \\
\text { protein }(\mu \mathrm{mol} / \mathrm{l})\end{array}$ & $7.2 \pm 0.5$ & $6.2 \pm 0.7$ & $7.0 \pm 0.4$ & $6.7 \pm 0.1$ & $6.5 \pm 0.2$ & $6.8 \pm 0.3$ & $6.7 \pm 0.3$ & $6.6 \pm 0.2$ \\
\hline $\begin{array}{l}\text { Free } 1,25-(\mathrm{OH})_{2} \mathrm{D}_{3} \\
\text { index }\end{array}$ & $0.82 \pm 0.04^{\mathrm{a}}$ & $1.54 \pm 0.20^{f}$ & $1.42 \pm 0.22^{i}$ & $1.83 \pm 0.39$ & $1.12 \pm 0.11^{a}$ & $1.76 \pm 0.18^{f}$ & $1.54 \pm 0.13^{f}$ & $1.64 \pm 0.10$ \\
\hline
\end{tabular}

Data are expressed as mean \pm SE. $25-\mathrm{OHD}_{3}=25$-hydroxyvitamin $\mathrm{D}_{3} ; 1,25-(\mathrm{OH})_{2} \mathrm{D}_{3}=1,25$-dihydroxyvitamin $\mathrm{D}_{3 .}{ }^{\text {a }} p<0.01$ vs. control values; ${ }^{\text {b }} p<0.05$ vs. control values; ${ }^{\mathrm{c}} p<0.001$ vs. control values; ${ }^{\mathrm{d}} p<0.05$ vs. values before vitamin $\mathrm{D}$ administration; ${ }^{\mathrm{e}} p<0.001$ vs. values before vitamin $\mathrm{D}$ administration; ${ }^{\mathrm{f}} p<0.01$ vs. values before vitamin $\mathrm{D}$ administration

Table 2. Fasting glucose and hormonal levels in epileptic and geriatric patients during vitamin $\mathrm{D}$ administration

\begin{tabular}{|c|c|c|c|c|c|c|c|c|}
\hline & \multicolumn{4}{|c|}{ Epileptic patients } & \multicolumn{4}{|c|}{ Geriatric patients } \\
\hline & $\begin{array}{l}\text { Before } \\
\text { treatment }\end{array}$ & $\begin{array}{l}1 \text { week after } \\
\text { treatment }\end{array}$ & $\begin{array}{l}2 \text { weeks after } \\
\text { treatment }\end{array}$ & $\begin{array}{l}\text { Control } \\
\text { values }\end{array}$ & $\begin{array}{l}\text { Before } \\
\text { treatment }\end{array}$ & $\begin{array}{l}1 \text { week after } \\
\text { treatment }\end{array}$ & $\begin{array}{l}2 \text { weeks after } \\
\text { treatment }\end{array}$ & $\begin{array}{l}\text { Control } \\
\text { values }\end{array}$ \\
\hline Glucose $(\mathrm{mmol} / \mathrm{l})$ & $3.8 \pm 0.1$ & $4.2 \pm 0.1$ & $4.0 \pm 0.1$ & $4.1 \pm 0.2$ & $4.5 \pm 0.3$ & $4.6-0.3$ & $4.3 \pm 0.2$ & $4.9 \pm 0.2$ \\
\hline Insulin $(\mathrm{mU} / \mathrm{l})$ & $14.8 \pm 2.3$ & $8.8 \pm 1.5^{\mathrm{a}}$ & $5.4 \pm 0.9^{a b}$ & $11.5 \pm 0.6$ & $10.4 \pm 1.7$ & $12.5 \pm 2.5$ & $10.1 \pm 1.5$ & $9.8 \pm 3.1$ \\
\hline Glucagon (pmol/1) & $12.5 \pm 3.0^{c}$ & $22.6 \pm 4.7^{\mathrm{a} d}$ & $21.3 \pm 3.1^{\mathrm{a}, \mathrm{d}}$ & $38.5 \pm 5.3$ & $23.3 \pm 2.3$ & $23.6 \pm 2.6$ & $23.4 \pm 2.2$ & $18.2 \pm 4.9$ \\
\hline
\end{tabular}

Data are expressed as mean \pm SE. ${ }^{a} p<0.01$ vs. values before vitamin $\mathrm{D}$ administration; ${ }^{b} p<0.001$ vs. control values; ${ }^{\mathrm{c}} p<0.01$ vs. control values; ${ }^{d} p<0.05$ vs. control values

\section{Study design}

Following an overnight fast, venous blood was collected before and after the ingestion of $75 \mathrm{~g}$ glucose for the measurement of glucose, insulin and glucagon. The blood samples were also used to measure biochemical parameters of calcium metabolism. The patients then received a loading dose of $200 \mu \mathrm{g} 25-\mathrm{OHD}_{3}$ (Dedrogyl, Roussel, Paris, France) followed by $10 \mu \mathrm{g}$ daily for 2 weeks. The evaluation of calcium metabolism and fasting hormonal values were repeated 1 week after vitamin $\mathrm{D}$ treatment. These parameters and the glucose tolerance test were evaluated again after 2 weeks of vitamin D supplementation.

\section{Biochemical methods}

Glucose, calcium, phosphorus, alkaline phosphatase and creatinine were measured on a SMAC continuous flow analyzer (Technicon Instruments, Tarrytown, New York, USA). Plasma ionized calcium was measured with an ion selective electrode (Nova 2 Ionized Analyzer, Nova Biomedical, Newton, Massachusetts, USA). The concentrations of serum $25-\mathrm{OHD}_{3}$ and vitamin D-binding protein were measured by competitive protein binding assay [11] and radial immunodiffusion [12] respectively. Serum parathyroid hormone and $1,25-(\mathrm{OH})_{2} \mathrm{D}_{3}$ were measured by radioimmunoassay as previously described $[13,14]$. The free $1,25-(\mathrm{OH})_{2} \mathrm{D}_{3}$ index was calculated as the molar ratio between the concentrations of this vitamin $\mathrm{D}$ metabolite and vitamin D-binding protein [15]. Serum insulin was determined using the charcoal-dextran radioimmunoassay technique [16], and plasma glucagon was determined by radioimmunoassay using blood samples collected in pre- chilled heparinized tubes containing aprotinin. The glucagon radioimmunoassay was carried out according to standard procedures using iodinated glucagon (New England Nuclear, Brussels, Belgium) and standard and antibody (UCB Bioproducts, Brussels, Belgium).

\section{Statistical analysis}

In the analysis of the effect of vitamin $D$ treatment on the parameters of calcium metabolism, analysis of variance with repeated measures was used. The Newman-Keuls method for testing a posteriori contrasts was used for comparisons among means [17]. The effect of vitamin $D$ on the secretion of pancreatic hormones was evaluated using the Student's t-test and the Wilcoxon test for paired observations. The Student's t-test for unpaired data and the Mann-Whitney test were used to compare means of independent groups. Data are expressed as mean $\pm S E$.

\section{Results}

\section{Evidence for subclinical vitamin $D$ deficiency}

Deficiency of vitamin $\mathrm{D}$ was demonstrated by low circulating concentrations of $25-\mathrm{OHD}_{3}$ and $1,25-(\mathrm{OH})_{2} \mathrm{D}_{3}$ in both groups of patients studied (Table 1). The mean level of $25-\mathrm{OHD}_{3}$ was clearly below the mean levels of 

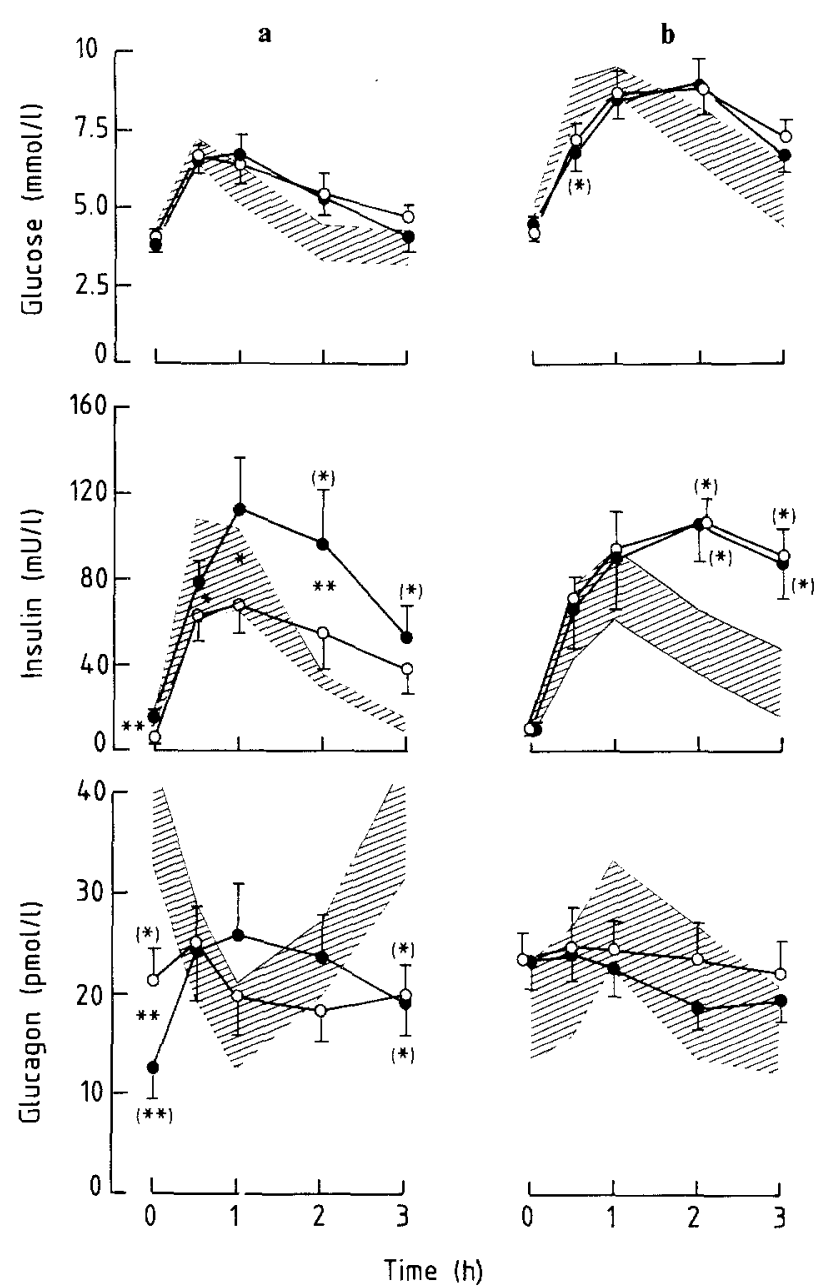

Fig. 1. Secretion curves of pancreatic hormones after glucose ingestion before $(\longrightarrow)$ and 2 weeks after $(\mathrm{O}-\mathrm{O}) 25-\mathrm{OHD}_{3}$ treatment in $\mathbf{a}$ epileptic and $\mathbf{b}$ geriatric patients. Hatched area represents normal range. *: $p<0.05$ vs. values before vitamin $\mathrm{D}$ administration; **: $p<$ 0.01 vs. values before vitamin $\mathrm{D}$ administration; $\left({ }^{*}\right): p<0.05$ vs. control values; $(* *): p<0.01$ vs. control values

the control populations. Half of the epileptic patients and $40 \%$ of geriatric patients had $25-\mathrm{OHD}_{3}$ values in the rachitic range $(<5 \mu \mathrm{g} / 1)$. The concentrations of total and "free" $1,25-(\mathrm{OH})_{2} \mathrm{D}_{3}$ were also decreased in both populations of patients compared with controls, but this decrease was more severe in epileptic patients than in geriatric patients. Other biochemical data were only disturbed in the epileptic patients as shown by decreased serum concentrations of calcium and phosphorus, and by increased levels of parathyroid hormone and alkaline phosphatase activity (Table 1). In the elderly patients only the serum phosphorus concentration was decreased. No clinical signs of osteomalacia were observed. The kidney function, as assessed by serum creatinine, was normal in both study groups. The short term $25-\mathrm{OHD}_{3}$ treatment restored serum vitamin $\mathrm{D}$ metabolites to normal. A significant increase in serum phosphorus concentration and suppression of parathyroid hormone secretion were found in both groups. However, serum calcium and alkaline phosphatase ac- tivity remained unchanged. The serum concentration of vitamin D-binding protein remained normal throughout the study.

\section{Fasting hormonal levels}

The fasting levels of pancreatic hormones are shown in Table 2. During vitamin D deficiency, fasting plasma glucose and insulin concentrations were normal in both epileptic and geriatric patients.

Glucagon concentration was normal in geriatric patients, but decreased in epileptic patients compared with controls. Vitamin D supplementation did not alter fasting glucose, insulin, or glucagon levels in geriatric patients; however, it decreased insulin and increased glucagon levels in epileptic patients.

\section{Response of pancreatic hormones to glucose}

During vitamin D deficiency, glucose tolerance was normal in epileptic patients; however, insulin levels were significantly higher than controls 2 and $3 \mathrm{~h}$ after glucose ingestion. Glucose tolerance was impaired and insulin release delayed in geriatric patients (Fig.1). After vitamin D repletion, the blood glucose curves remained unchanged. Insulin release did not change in geriatric patients, but was reduced by $35 \%$ in epileptic patients (Figs. 1 and 2).

In both control subjects and vitamin D-deficient elderly patients, no suppression of glucagon secretion by glucose loading was observed. Vitamin D supplementation in elderly patients did not restore glucagon response to glucose. In younger healthy subjects, glucagon levels decreased after glucose, whereas in vitamin D-deficient epileptic patients they increased. Inhibition of glucagon secretion by glucose tended to be restored after vitamin $\mathrm{D}$ supplementation in these patients (Fig. 1).

\section{Discussion}

We investigated glucose tolerance and secretion of pancreatic hormones before and after vitamin $\mathrm{D}$ repletion in mildly vitamin $\mathrm{D}$-deficient patients. Low serum $25-\mathrm{OHD}_{3}$ and $1,25-(\mathrm{OH})_{2} \mathrm{D}_{3}$ concentrations were found in both groups of patients. Vitamin D deficiency was more severe in the epileptic patients, as their serum calcium, alkaline phosphatase and parathyroid hormone concentrations were also disturbed. In both groups the serum concentration of $1,25(\mathrm{OH})_{2} \mathrm{D}_{3}$ increased rapidly to normal after $25-\mathrm{OHD}_{3}$ supplementation (Table 1). This clearly demonstrates the presence of a functioning renal $25-\mathrm{OHD}_{3}-1 \alpha$-hydroxylase activity, and further supports the conclusion that the $25-\mathrm{OHD}_{3}$ concentration before vitamin $D$ treatment was insufficient for optimal production of the vitamin D hormone. The increase in serum phosphorus and the decrease in 

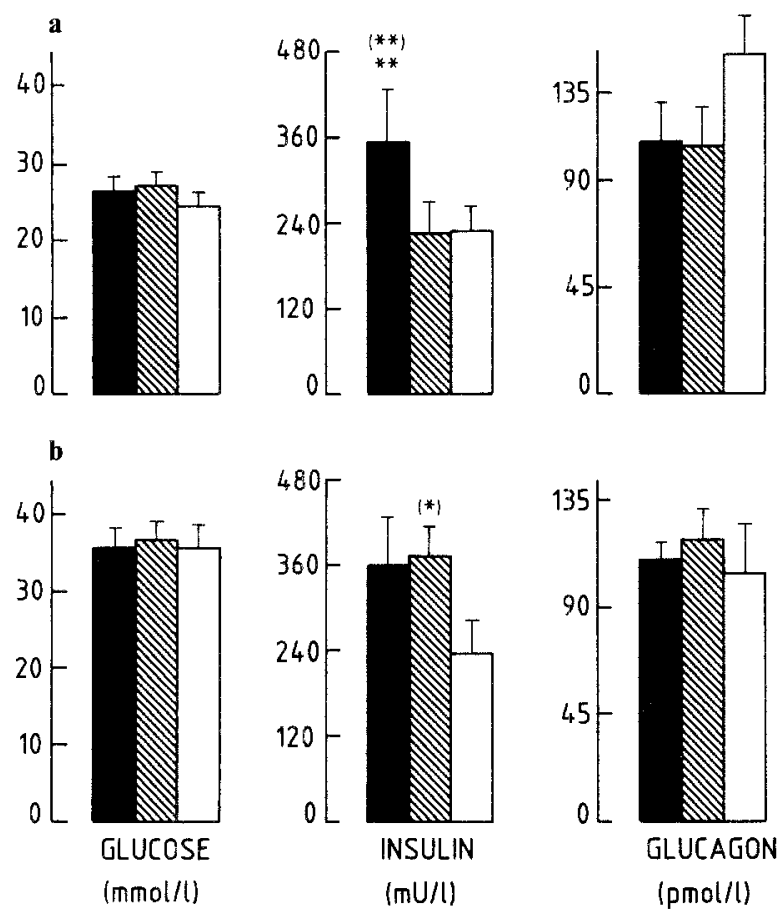

Fig. 2. Total sum of blood glucose and pancreatic hormones during oral glucose tolerance test in $\mathbf{a}$ epileptic and $\mathbf{b}$ geriatric patients before (ם) and after ( $\mathbb{\$}$ ) vitamin D treatment, and in normal subjects ( $\square$ ). **: $p<0.01$ vs. values before vitamin D treatment; $\left({ }^{*}\right): p<0.05$ vs. control values; $(* *): p<0.01$ vs. control values

parathyroid hormone after vitamin $\mathrm{D}$ repletion also suggest pre-existent vitamin $\mathrm{D}$ deficiency.

Recent animal studies have shown that vitamin $D$ is essential for the normal function of pancreatic B cells [5-9]. In the present study, however, we were unable to observe an increase in basal or glucose-stimulated insulin secretion after correction of vitamin D deficiency. This discrepancy could be explained by the much more pronounced vitamin D deficiency obtained in experimental animals. The decreased insulin secretion after vitamin D treatment in epileptic patients is not explained. An effect of diphenylhydantoin is unlikely, since the same amount of drug was administered throughout the study [18]. Other data also indicate that vitamin $\mathrm{D}$ administration is not always followed by increased insulin secretion and may even be associated with decreased release of this hormone. In a study by Kawashima et al. [19], insulin concentrations were decreased in obese ob/ob mice treated with $1 \alpha$-hydroxyvitamin $\mathrm{D}$, but remained unchanged in lean animals. Chertow et al. [20] found inhibitory effects of high doses of $1,25-(\mathrm{OH})_{2} \mathrm{D}_{3}$ on insulin secretion by isolated rat pancreatic islets, but no effect of physiological doses of this sterol. Likewise, Frankel et al. [21] found no effect of $1,25-(\mathrm{OH})_{2} \mathrm{D}_{3}$ on insulin secretion by mouse pancreatic islets.

In contrast to the hypoinsulinaemia of severely vitamin D-deficient animals, we observed a delayed hypersecretion of insulin in mildly vitamin D-deficient ep- ileptic patients. Vitamin D repletion normalized their insulin secretion. This could thus be an indication that vitamin $\mathrm{D}$ deficiency decreased the peripheral insulin sensitivity of the epileptic patients. The insulin secretion of the geriatric vitamin D-depleted patients was also delayed and increased above normal; however, it was not corrected by short-term vitamin D repletion and is therefore less likely to be due to vitamin $\mathrm{D}$ deficiency.

Vitamin D-deficient patients presented a lack of responsiveness of the A cells to glucose. Indeed, fasting glucagon level was markedly lower in D-deficient epileptic patients than in control subjects, and ingestion of glucose by these patients paradoxically increased glucagon levels instead of suppressing them (Fig. 1), a situation previously reported in diabetic and prediabetic states $[10,22,23]$. Vitamin $D$ treatment tended to restore the glucose sensitivity of the A cells in these patients. Glucagon levels in geriatric patients were comparable to control values, and were non-suppressible by glucose.

Our observations confirm the high frequency of subclinical vitamin D deficiency in epileptic and homeconfined geriatric patients. We investigated the secretion of pancreatic hormones comparing each group of patients with controls, and before and during vitamin D supplementation. These longitudinally collected data demonstrate that vitamin $\mathrm{D}$ deficiency is associated with a delayed insulin response and a resistance of glucagon secretion to glucose. Vitamin D repletion did not increase insulin secretion or improve glucose tolerance in man.

Acknowledgements. The authors wish to thank Mr I Jans, J Laureys, E Van Herck, and W Coopmans, Laboratorium voor Experimentele Geneeskunde en Endocrinologie for their skillful technical assistance. This work was supported by the Belgian Fonds voor Geneeskundig Wetenschappelijk Onderzoek (Grant n. 3.0019.81 and 3.004079).

\section{References}

1. Fraser DR (1980) Regulation of the metabolism of vitamin D. Physiol Rev 60: 551-613

2. Marx SJ, Liberman UA, Eil C (1983) Calciferols: actions and deficiencies in action. Vitam Horm 40: 235-308

3. Clark SA, Stumpf NE, Sar M, DeLuca HF, Tanaka Y (1980) Target cells for 1,25 -dihydroxyvitamin $\mathrm{D}_{3}$ in the pancreas. Cell Tissue Res 209: 515-520

4. Roth J, Bonner-Weir S, Norman AW, Orci L (1982) Immunocytochemistry of vitamin D-binding protein in chick pancreas: exclusive localization in B-cells. Endocrinology 110: 2216-2218

5. Clark SA, Stumpf WE, Sar M (1981) Effect of 1,25-dihydroxyvitamin $\mathrm{D}_{3}$ on insulin secretion. Diabetes $30: 382-386$

6. Norman AW, Frankel BJ, Heldt AM, Grodsky GM (1980) Vitamin $D$ deficiency inhibits pancreatic secretion of insulin. Science 209: $823-825$

7. Nyomba BL, Bouillon R, De Moor P (1984) Influence of vitamin $D$ status on insulin secretion and glucose tolerance in the rabbit. Endocrinology 115: 191-197

8. Kadowaki S, Norman AW (1984) Dietary vitamin D is essential for normal insulin secretion from the perfused rat pancreas. J Clin Invest 73:759-766 
9. Ishida H, Seino Y, Seino S, Tsuda K, Takemura J, Nishi S, Ishizuka $S$, Imura $H$ (1983) Effect of 1,25-dihydroxyvitamin $D_{3}$ on pancreatic B and D cell function. Life Sci 33: 1779-1786

10. Felig P, Sherwin RS, Soman V, Wahren J, Hendler R, Sacca L, Eigler N, Goldberg D, Walesky M (1979) Hormonal interactions in the regulation of blood glucose. Rec Progr Horm Res 35: $501-532$

11. Bouillon R, Van Kerkhove P, De Moor P (1976) Measurement of 25-hydroxyvitamin $\mathrm{D}_{3}$ in serum. Clin Chem $22: 364-368$

12. Bouillon R, Van Baelen H, De Moor P (1977) The measurement of vitamin D-binding protein in human serum. J Clin Endocrinol Metab 45: 225-231

13. Bouillon R, De Moor P (1977) Parathyroid hormone secretion in primary hyperparathyroidism. J Clin Endocrinol Metab 45: 261-269

14. Bouillon R, De Moor P, Baggiolini EG, Uskokovic MR (1980) A radioimmunoassay for 1,25-dihydroxycholecalciferol. Clin Chem 26:562-567

15. Bouillon R, Van Assche FA, Van Baelen H, Heyns H, De Moor $P$ (1981) Influence of the vitamin D-binding protein on the serum concentration of 1,25-dihydroxyvitamin $\mathrm{D}_{3}$. Significance of the free 1,25-dihydroxyvitamin $D_{3}$ concentration. J Clin Invest 67 : $589-596$

16. Albano JDM, Ekins RP, Maritz G, Turner RC (1972) A sensitive, precise radioimmunoassay of serum insulin relying on charcoal separation of bound and free hormone moieties. Acta Endocrinol 70: 487-509

17. Snedecor GW, Cochran WG (1967) Statistical methods. The Iowa State University Press, Ames, Iowa, p 301
18. Fariss BL, Lutcher CL (1971) Diphenylhydantoin-induced hyperglycemia and impaired insulin release. Effect of dosage. Diabetes 20:177-181

19. Kawashima $H$, Castro A (1981) Effect of $1 \alpha$-hydroxyvitamin $D_{3}$ on the glucose and calcium metabolism in genetic obese mice. Res Commun Chem Pathol Pharmacol 33: 155-161

20. Chertow BS, Sivitz WI, Baranetsky NG, Clark SA, Waite A, DeLuca HF (1983) Cellular mechanism of insulin release: the effects of vitamin D deficiency and repletion on rat insulin secretion. Endocrinology 113: 1511-1518

21. Frankel BJ, Schlin J, Taljedal B (1984) Vitamin $D_{3}$ stimulates ${ }^{45} \mathrm{Ca}^{2+}$ uptake by mouse islets in vitro. Diabetes 33:154A

22. Pek S (1977) Glucagon and diabetes. Clin Endocrinol Metab 6: 333-344

23. Unger RH, Dobbs RE, Orci L (1978) Insulin, glucagon, and somatostatin secretion in the regulation of metabolism. Ann Rev Physiol 40: 307-343

Received: 8 February 1985

and in revised form: 23 October 1985

Professor Roger Bouillon

Laboratorium Experimentele Geneeskunde en Endocrinologie

Onderwijs en Navorsing

Gasthuisberg

B-3000 Leuven

Belgium 